\title{
Potensi Longsor di Kabupaten Kendal, Provinsi Jawa Tengah Berdasarkan Penginderaan Jauh
}

\author{
Garindra Yogiswara ${ }^{1 *}$, Thomas Triadi Putranto ${ }^{1}$, Devina Trisnawati ${ }^{1}$ \\ ${ }^{1}$ Departemen Teknik Geologi, Fakultas Teknik, Universitas Diponegoro, Semarang
}

\begin{abstract}
Abstrak
Kabupaten Kendal, Jawa Tengah memiliki riwayat longsor 206 kejadian pada 2010-2020, menyebabkan 41 bangunan rusak dan 28 warga mengungsi. Hal ini menunjukkan bahwa longsor adalah kejadian yang serius dan perlu menjadi perhatian. Peta resmi kerentanan longsor oleh PVMBG dan Badan BPBD Kabupaten Kendal berskala regional perlu pembaruan kelengkapan data dan informasi. Penelitian bertujuan membuat zona potensi longsor untuk rekomendasi perencanaan dan pembangunan. Citra SPOT 6 dan 7 digunakan untuk interpretasi penggunaan lahan, curah hujan dari citra Himawari-8 2019, interpretasi litologi dan kelurusan (divalidasi dari data Pusat Survey Geologi 2013 dan lapangan), serta kemiringan lereng dari DEM. Kalkulasi merupakan kombinasi klasifikasi DVMBG 2004, BBPPSDLP 2009, dan PVMBG 2015. Zona potensi longsor rendah (44,05\% atau 44.220 Ha) meliputi Kota Kendal, Patebon, Kaliwungu Utara, Brangsong, Kangkung, Patebon, Cepiring, Rowosari, Weleri dan Pegandon bagian utara, Gemuh bagian utara, Ringinarum bagian utara. Zona potensi longsor sedang $(50,47 \%$ atau $50.661 \mathrm{Ha}$ ) meliputi Kaliwungu Selatan, Boja, Plantungan bagian utara, Sukorejo bagian utara, Pegandon bagian selatan, Gemuh bagian selatan, Ngampel bagian utara, Ringinarum bagian selatan, dan Patean bagian selatan. Potensi longsor tinggi $(5,48 \%$ atau $5.500 \mathrm{Ha}$ ) meliputi Singorojo bagian utara dan barat, Sukorejo bagian selatan, Plantungan bagian selatan, Pageruyung bagian timur, Limbangan barat dan selatan, serta Patean bagian utara. Potensi longsor sangat tinggi $(0,001 \%$ atau $1,3 \mathrm{Ha})$ meliputi daerah Sumber Rahayu dan Sriwulan Limbangan.
\end{abstract}

Kata kunci: Citra SPOT; Kabupaten Kendal; longsor; pembobotan; penginderaan jauh.

\begin{abstract}
Kendal, Central Java has 206 landslides incidents in 2010-2020, caused 41 buildings to be damaged, and 28 people to be evacuated. It shows that landslides are hazardous. The official map of potential landslides created by BPDB and PVMBG (regional scale) needs to be updated with more complete information. This study aims to create potential landslides zones to be a recommendation for further research and development planning. The data used includes SPOT 6 and 7 that have been pan sharped to identify land use, rainfall obtained from the Himawari-8 satellite in 2019, lithological interpretation, and lineament validated with data from regional geology of Pusat Survey Geologi, and slope from the DEM data. The calculations according to a combination of DVMBG 2004, BBPPSDLP 2009, and $P V M B G 2015$ classification. The results show that northern Kendal, Patebon, North Kaliwungu, Brangsong, Kangkung, Patebon, Cepiring, Rowosari, northern Weleri, Pegandon, northern Gemuh, and northern Ringinarum has low landslide potential (44.05\% or 44,220 Ha). Southern Kaliwungu, Boja, northern Plantungan, northern Sukorejo, southern Pegandon, southern Patean, northern Ngampel, northern Ringinarum has middle landslide potential $(50,47 \%$ or $50.661 \mathrm{Ha})$. Northern and western Singorojo, southern Sukorejo, southern Plantungan, eastern Pageruyung, western and southern Limbangan, and northern Patean has high landslide potential (5,F48\% or $5.500 \mathrm{Ha}$ ). Sumber Rahayu and Sriwulan, Limbangan has very high landslide potential $(0,001 \%$ or $1,3 \mathrm{Ha})$.
\end{abstract}

Keyword: SPOT Imagery; Kendal Regency; landslide; weighting methods; remote sensing.

\footnotetext{
* Korespondensi: garindrayogi98@gmail.com
} 


\section{PENDAHULUAN}

Pusat Vulkanologi Mitigasi Bencana Geologi (PVMBG) tahun 2019 menyebutkan bahwa Provinsi Jawa Tengah memiliki riwayat longsor sebanyak 801 kejadian antara tahun 2006-2018 dan menyebabkan 609 orang meninggal dunia. Sebagian besar wilayah di Jawa Tengah memiliki indeks risiko bencana longsor cukup tinggi. Salah satu diantaranya adalah Kabupaten Kendal (206 titik pada 2010-2020). Peta prediksi dari PVMBG tiap bulannya bersifat regional belum memuat informasi spesifik pada tiap wilayahnya. Intensitas kejadian longsor yang tergolong cukup tinggi diperlukan penelitian sebagai langkah mitigasi bencana, pembaruan data dan informasi, serta rekomendasi pengembangan wilayah.

Perkembangan penginderaan jauh banyak digunakan untuk penelitian termasuk geologi, terutama skala luas. Beberapa penelitian menggunakan citra SPOT dan IKONOS untuk deteksi longsor di Lantau, Hongkong (Nichol dan Wong, 2005a; Nichol dan Wong 2005b). Sukojo dan Citra (2018) menggunakan beberapa citra (salah satunya citra SPOT) untuk analisis longsor di daerah Tuban dengan metode pembobotan. Zhong, dkk. (2019) menjelaskan dalam penelitiannya tentang manfaat dan tantangan penginderaan jauh untuk pemetaan longsor dengan Lidar, DinSAR. Dewi dkk. (2017) menggunakan penginderaan jauh dari beberapa citra dan metode pembobotan menurut kombinasi dari PVMBG (2015), DVMBG (2004), dan BBPPSDLP (2009) untuk zonasi longsor di Purworejo, Jawa Tengah. Ini membuktikan penginderaan jauh efektif dan banyak digunakan untuk identifikasi longsor wilayah luas.

Metode pembobotan disesuaikan dengan kondisi daerah penelitian, dimana terdapat beberapa aspek seperti penggunanan lahan, indikasi kelurusan, jenis batuan, curah hujan, dan kemiringan lereng. Semua hal tersebut dianggap mempengaruhi terjadinya longsor. Parameterparameter tersebut dikalkulasikan pada klasifikasi yang tepat menurut Direktorat Vulkanologi dan Mitigasi Bencana Geologi (DVMBG) tahun 2004, Balai Besar Penelitian dan Pengembangan Sumberdaya Pertanian (BBPPSDLP) tahun 2009, dan Pusat Vulknaologi dan Bencana Geologi (PVMBG) tahun 2015. Hal ini diperkuat oleh penelitian Dewi dkk. (2017) yang memakai metode tersebut.
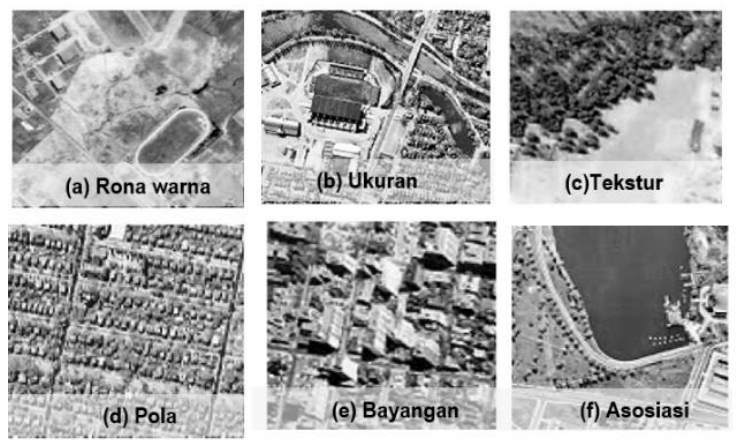

Gambar 1. Unsur Interpretasi citra (CCRS, 2018).

Tujuan akhir dari penelitian ini untuk menghasilkan peta zona rawan longsor disertai dengan pengecekan lapangan, sehingga peta ini diharapkan menjadi acuan untuk berbagai pihak dalam mitigasi bencana serta rekomendasi wilayah dalam perencanaan pembangunan.

\section{Geologi Regional}

Formasi batuan di wilayah penelitian menurut Thanden dkk. (1996) diawali dengan terbentuknya intrusi basalt dan andesit (awal Tersier, terangkat lalu tererosi. Hasil erosi inilah yang membentuk material sedimen turbidit Formasi Kerek pada Lingkungan neritik sampai laut dalam. Saat ini persebaran Formasi Kerek terdapat di sekitar Patean dan Singorojo bagian barat. Selanjutnya Formasi Penyatan yang ada di sekitar Limbangan dan Singorojo. Formasi Damar dan Formasi Kaligetas terbentuk hampir bersamaan. Formasi Damar mengendap lebih lama dari Formasi Kaligetas. Proses selanjutnya adalah jeda pengendapan yang mengakibatkan Formasi Damar dan Kaligetas berhubungan secara ketidakselarasan dengan formasi selanjutnya. Pada Kuarter, terbentuk batuan batuan vulkanik meliputi Formasi Jembangan, Formasi Gajahmungkur, Formasi Jongkong, serta Formasi Kaligesik. Aktifnya tektonik pada PlioPleistosein menyebabkan terbentuknya lipatan, sesar naik yang arahnya relatif barat-timur, sesar geser berarah timur laut-barat dan tenggara-barat laut, dan sesar normal. Sesar-sesar ini dapat dilihat pada geologi regional daerah penelitian. Zona lemah inilah yang diindikasikan menjadi jalur munculnya gunungapi umur kuarter terbentuk. Hasil erosi dan trasportasi dari formasi-formasi tersebut terendapkan pada bagian utara Kendal dan menyusun material endapan aluvium (Gambar 2). 


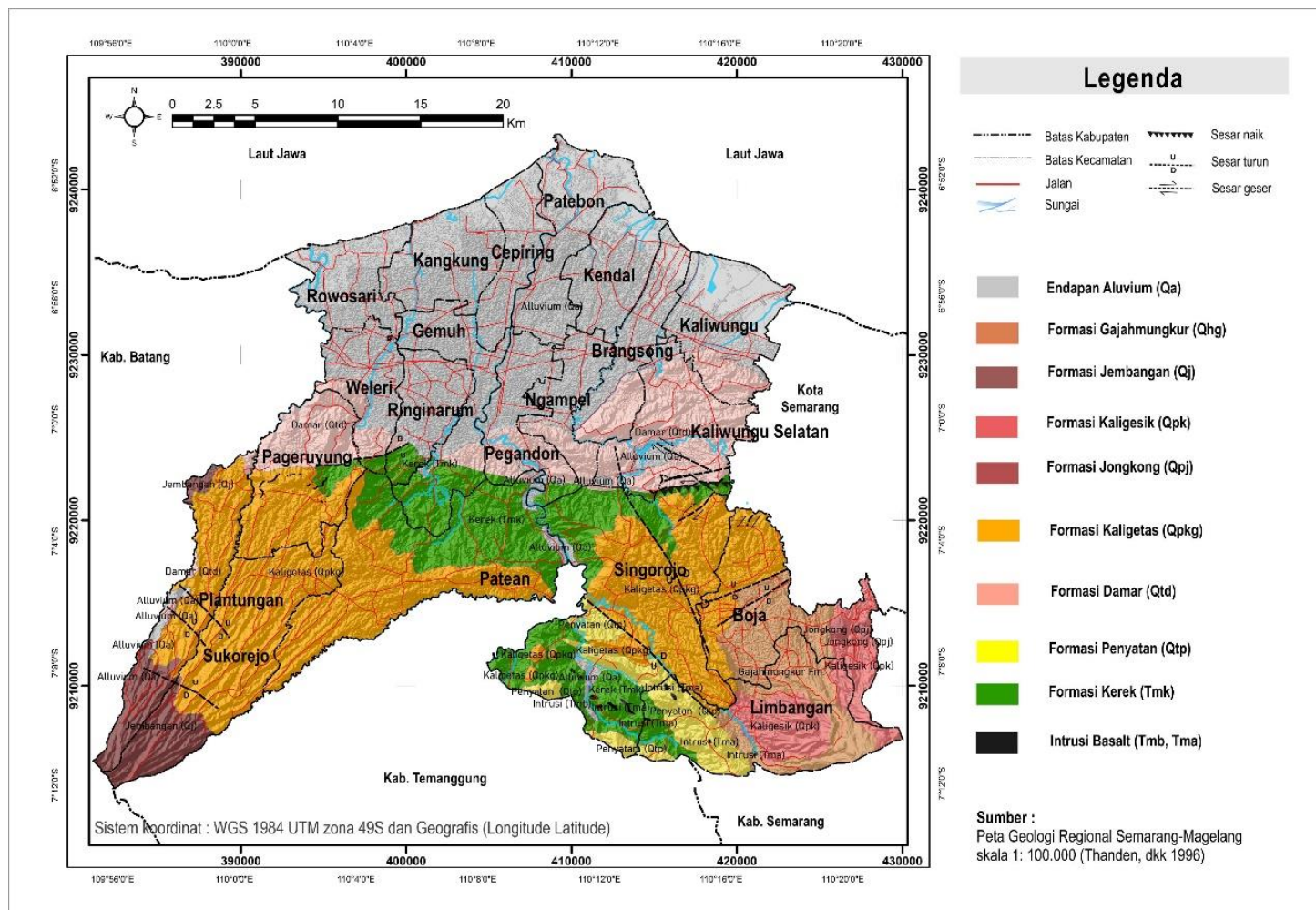

Gambar 2. Geologi regional Kendal (modifikasi dari Thanden, dkk. 1996).

\section{Interpretasi Penginderaan Jauh}

Lillesand dan Kiefer (1979) menjelaskan bahwa penginderdaan jauh adalah ilmu mendapatkan informasi objek atau daerah dengan menganalisis data dari alat tanpa kontak langsung dengan objek tersebut. Penginderaan jauh secara pasif menggunakan energi dari matahari yang dipantulkan langsung dari objek, contohnya Landsat, SPOT. Penginderaan jauh secara aktif menyediakan sumber radiasi elektromagnetik sendiri untuk memancarkan data dari objek, contohnya radar. Objek pada citra (Gambar 1) diidentifikasi dengan memperhatikan rona warna, bentuk, ukuran, tekstur, pola, bayangan, dan asosiasi (CCRS, 2018)

\section{Citra SPOT 6/ 7, DEMNAS, dan Himawari-8}

Citra SPOT 6 dan 7 diluncurkan pada September 2012 dan 2014 diluncurkan citra menggantikan citra SPOT 4 dan citra ini memiliki resolusi spasial 1,5 meter (pansharpe, dan 8 meter pada multispectral $(R / G / B / N I R)$ dengan lebar sapuan sebesar $60 \mathrm{Km}$ (Astrium, 2019) dan kapasitas perekaman harian $3.000 .000 \mathrm{~km}^{2}$ pada tiap satelit. Kanal atau bands yang dimiliki meliputi panchromatic $(0,450-0,745 \mu \mathrm{m})$, blue $(0,450$ $0,520 \mu \mathrm{m})$, green $(0,530-0,590 \mu \mathrm{m})$, red $(0,625-$ $0,695 \mu \mathrm{m})$ near infrarred $(0,760-0,890 \mu \mathrm{m})$. Citra

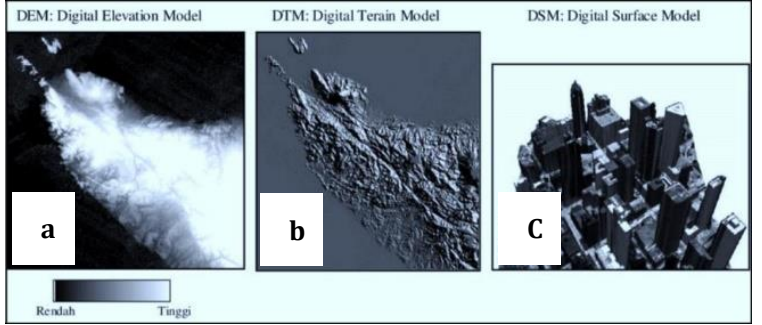

Gambar 3. Perbedaan DEM (a), DTM (b), dan DSM (c) (Emiyati, 2012).

SPOT Kendal ditampilkan pada Gambar 4.

Citra Himawari-8 mengakuisisi data di Asia timur-Australia, digunakan untuk prediksi cuaca jangka pendek (nowcasting) dan jangka panjang (Kushardono, 2012). Citra Himawari-8 Potential Rainfall adalah produk dari citra Himawari yang digunakan untuk memprediksi potensi curah hujan. Disajikan dalam kategori ringan, sedang, lebat, hingga sangat lebat dengan memperhatikan faktor suhu puncak awan dengan potensi curah hujan. Citra Himawari 8 memiliki sensor Advanced Himawari Imager (AHI), untuk meningkatkan resolusi spektral, spasial, dan temporal, dengan 16 band ( 3 band visible, 3 band near-infrared (NIR), dan 10 band thermal atau inframerah (IR)), memiliki resolusi per pixel sebesar $0,5 \mathrm{~km}$ dan $1 \mathrm{~km}$ pada cahaya tampak, 2 $\mathrm{km}$ pada IR serta $1 \mathrm{~km}$ dan $2 \mathrm{~km}$ pada NIR dan 
resolusi tenporal 30 menit.

DEM adalah ilustrasi dari permukaan suatu daerah dengan memperhatikan nilai ketinggian untuk merepresentasikan bentuk kontur yang informasi ketinggian dan diilustrasikan dengan perbedaan warna (Yu dan Chen, 2017). Umumnya terdapat 2 jenis yang berhubungan dengan DEM, yakni Digital Terrain Model (DTM) dan Digital Surface Model (DSM). DEM (warna hitam memperlihatkan daerah topografi rendah, sedangkan warna putih memperlihatkan daerah topografi tinggi) (Gambar 3.a). DTM merupakan model permukan tanpa pengaruh dari objek diantasnya seperti pohon, bangunan dan sejenisnya (Gambar 3.b). DSM merupakan model permukan dengan memperhatikan semua yang di atas permukaan diatasnya seperti pohon, bangunan dan sejenisnya (Gambar 3.c)

\section{Longsor}

Highland dan Bobrowsky (2008) menjelaskan longsor adalah kejadian gerakan material baik berupa batuan, gerakan tanah, dan material lainnya pada lereng dari pengaruh gravitasi. Jenis longsor (Highland dan Bobrowsky, 2008) yang serupa dengan Varnes (1978) meliputi tipe rotational slide yang dicirikan bidang gelincir melengkung, translational slide yang dicirikan bidang gelincir cenderung rata, blockslide yang dicirikan bidang gelincir berupa block batuan, rockfall yang dicirikan bongkah jatuh, topples yang dicirikan beberapa kelompok bongkah yang jatuh dalam sumbu yang sama, debris flow yan dicirikan aliran massa, debris avalanche yang dicirikan aliran massa yang bermula dari longsoran hampir sama dengan slide, earthflow yang dicirikan aliran massa yang lambat dan agak datar, creep yang dicirikan gerakan membentuk rekahan dari suatu bidang, serta lateral spread yang dicirikan gerakan rekahan pada bidang yang cenderung datar.

Beberapa penelitian menyebutkan longsor dipengaruhi oleh jenis batuan, curah hujan, jarak dari patahan, tutupan lahan, dan kondisi tanah. Liu dan Mason (2016) menjelaskan kelurusan pada citra membantu penentuan gerakan tanah terhadap aktivitas tektonik di sekitarnya. Kelurusan dapat mengetahui kondisi struktur makro daerah untuk mengidentifikasi zona lemah (Thannoun, 2003).

\section{METODOLOGI}

Beberapa proses dilakukan meliputi analisis data penginderaan jauh yaitu interpretasi citra SPOT 6 dan 7 secara digital (supervised randoom forest classification) melalui plattfrom Google Earth Engineer untuk penggunaan lahan, DEMNAS untuk interpretasi kelurusan, jenis batuan secara umum, kemiringan lereng dengan menampilkan hillshade sudut $\left(45^{\circ}, 90^{\circ}, 180^{\circ}\right.$, dan $\left.270^{\circ}\right)$. Penentuan sudut hillshade didasarkan pada

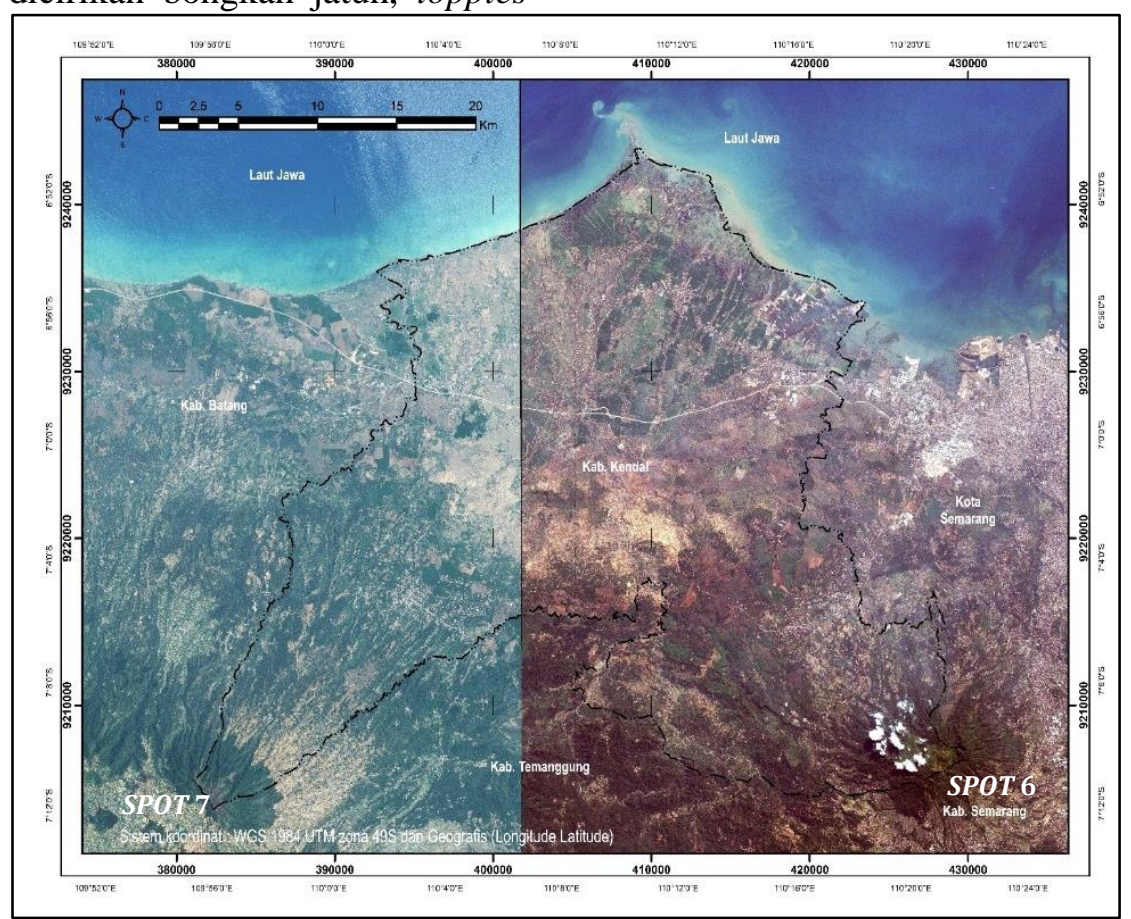

Gambar 4. Kenampakan Citra SPOT 6 dan 7 Kabupaten Kendal (LAPAN, 2019). 
Tabel 1. Parameter dan presentase pembobotan penelitian.

\begin{tabular}{|c|c|c|c|c|c|c|}
\hline \multirow[b]{2}{*}{ Parameter } & \multicolumn{5}{|c|}{ Skor (Pengaruh Terhadap Longsor) } & \multirow[b]{2}{*}{ Bobot } \\
\hline & $\begin{array}{c}1 \\
\text { (sangat rendah) }\end{array}$ & $\begin{array}{c}2 \\
\text { (rendah) }\end{array}$ & $\begin{array}{c}3 \\
(\text { sedang) }\end{array}$ & $\begin{array}{c}4 \\
\text { (tinggi) }\end{array}$ & $\begin{array}{c}5 \\
\text { (sangat tinggi) }\end{array}$ & \\
\hline Kelerengan & $<8 \%$ & $8-15 \%$ & $16-25 \%$ & $26-45 \%$ & $>45 \%$ & $35 \%$ \\
\hline Jenis batuan & Aluvium & vulkanik & sedimen & - & - & $25 \%$ \\
\hline Jenis Lahan & Hutan & Perkebunan & Persawahan & Lahan terbangun & Lahan terbuka & $10 \%$ \\
\hline $\begin{array}{l}\text { Jarak dari } \\
\text { kelurusan } \\
\text { (m) }\end{array}$ & $>800$ & $500-800$ & $301-500$ & $100-300$ & $<100$ & $10 \%$ \\
\hline $\begin{array}{l}\text { Curah hujan } \\
\text { (mm/ tahun) }\end{array}$ & - & $1.997-2.000$ & $2.001-2.500$ & $2.501-3.000$ & $3.001-3.197$ & $20 \%$ \\
\hline
\end{tabular}

kenampakan terbaik untuk menampilkan bentukan kelurusan. Pengoalahan sistem informasi geografis meliputi koreksi dan merapikan data interpretasi penggunaan lahan, menggabungkan berbagai macam aspek dalam peta sesuai kebutuhan, mengubah dari vektor ke raster, serta melakukan layouting peta.

Pembagian kelas dari kelas 1 sampai 5 pada tiap parameter (curah hujan 20\%, jenis batuan $25 \%$, jarak dari kelurusan $10 \%$, penggunaan lahan $10 \%$, kemiringan lereng 35\%) dilakukan dengan raster calculator sesuai presentase dan dibagi 5 (sesuai jumlah parameter) pada aplikasi ArcGis. Pembobotan tersebut akan menghasilkan rentang nilai akhir, nilai tertinggi sampai terendah kemudian dikelaskan kembali untuk mendapatkan zona potensi longsor, yaitu 0-1 sangat rendah, 1,01-2 rendah, 2,01-3 sedang, 3,01-4 tinggi, 4,01-5 sangat tinggi.

\section{HASIL}

\section{Penggunaan Lahan}

Kenampakan pada citra yang menunjukkan tubuh air berwarna kebiruan, hutan (heterogen dan homogen) kenampakan warna hijau tua, bentuk cenderung tak beraturan, tekstur yang cukup kasar sampai kasar, hutan heterogen memiliki tekstur yang lebih kasar daripada hutan homogen. Persawahan berwarna hijau muda, berbentuk pola kotak-persegi panjang dan cukup beraturan. Perkebunan berwarna hijau muda-tua, teksturnya tidak lebih kasar dari hutan homogen dan heterogen, serta asosiasinya banyak yang dekat dengan pemukiman. Lahan terbangun berwarna putih-abu-abu-merah, membentuk pola beraturan persegi-persegi panjang, berasosiasi dengan jalan. Lahan terbuka warnanya coklat, jarang dijumpai vegetasi.
Interpretasi penggunaan lahan menunjukkan Kabupaten Kendal didominasi oleh persawahan $(31,58 \%)$, perkebunan $(12,59 \%)$, hutan $(34,23 \%)$ berupa hutan homogen (tanaman industri karet, pinus, jati, cengkeh) dan hutan heterogen (didominasi di Limbangan, Sukorejo, Plantungan, Singorojo, dan Plantungan, dan Boja), lahan terbuka $(8,18 \%)$ terdapat di sekitar Patean, dan lahan terbangun $(7,97 \%)$ terdapat di sekitar Sukorejo, Kendal, Weleri, Boja, dan Kaliwungu. Lahan terbuka umumnya digunakan untuk ladang, penambangan, serta alih fungsi lahan.

Penggunaan lahan lahan terbuka beresiko sangat tinggi karena tak adanya vegetasi yang menahan kekuatan antar tanah atau batuan. Lahan terbangun beresiko tinggi, karena beban pada atas permukaan tanah memicu tekanan pada tanah atau batuan. Persawahan beresiko sedang karena tanahnya basah akibat pengairan, dan tanaman yang kurang kuat akarnya. Perkebunan beresiko rendah karena banyak dijumpai banyak tanaman yang dapat mengurangi resiko longsor. Hutan (homogen dan heterogen) paling aman karena banyak tanaman dengan akar kuat yang mencegah longsor. Alih fungsi lahan juga mempengaruhi longsor. Penggunaan lahan mempengaruhi longsor sebanyak $10 \%$ (Tabel 2 dan Gambar 5).

\section{Kemiringan Lereng}

Klasifikasi kemiringan lereng yang dimodifikasi menurut van Zuidam (1985) yang dijelaskan pada Tabel 3. Hal ini sesuai dengan kondisi lapangan, dimana umumnya daerah Kabupaten Kendal bagian utara merupakan yang daerah yang landai, Kendal bagian merupakan daerah berbukit bergelombang, sedangkan Kendal bagian 
Tabel 2. Rincian pembobotan penggunaan lahan.

\begin{tabular}{ccccc}
\hline Penggunaan Lahan & Persebaran wilayah & Skor & $\begin{array}{c}\text { Pengaruh } \\
\text { longsor }\end{array}$ & Luas (Ha) \\
\hline Tubuh air & Kendal bagian utara & - & - & 5.483 \\
Hutan homogen & Limbangan, Singorojo, Sukorejo, & 1 & Sangat rendah & 34.368 \\
Dan heterogen & Plantungan dan sekitarnya & & & \\
Perkebuan & Limbangan, Sukorejo dan sekitarnya & 2 & Rendah & 12.637 \\
Persawahan & Kendal bagian utara & 3 & Sedang & 31.703 \\
Lahan terbangun & Kendal, Weleri, Boja, Sukorejo, & 4 & Tinggi & 8.002 \\
Lahan terbuka & Kaliwungu & 5 & Sangat Tinggi & 8.210 \\
& Patean dan sekitarnya & & & \\
\hline
\end{tabular}
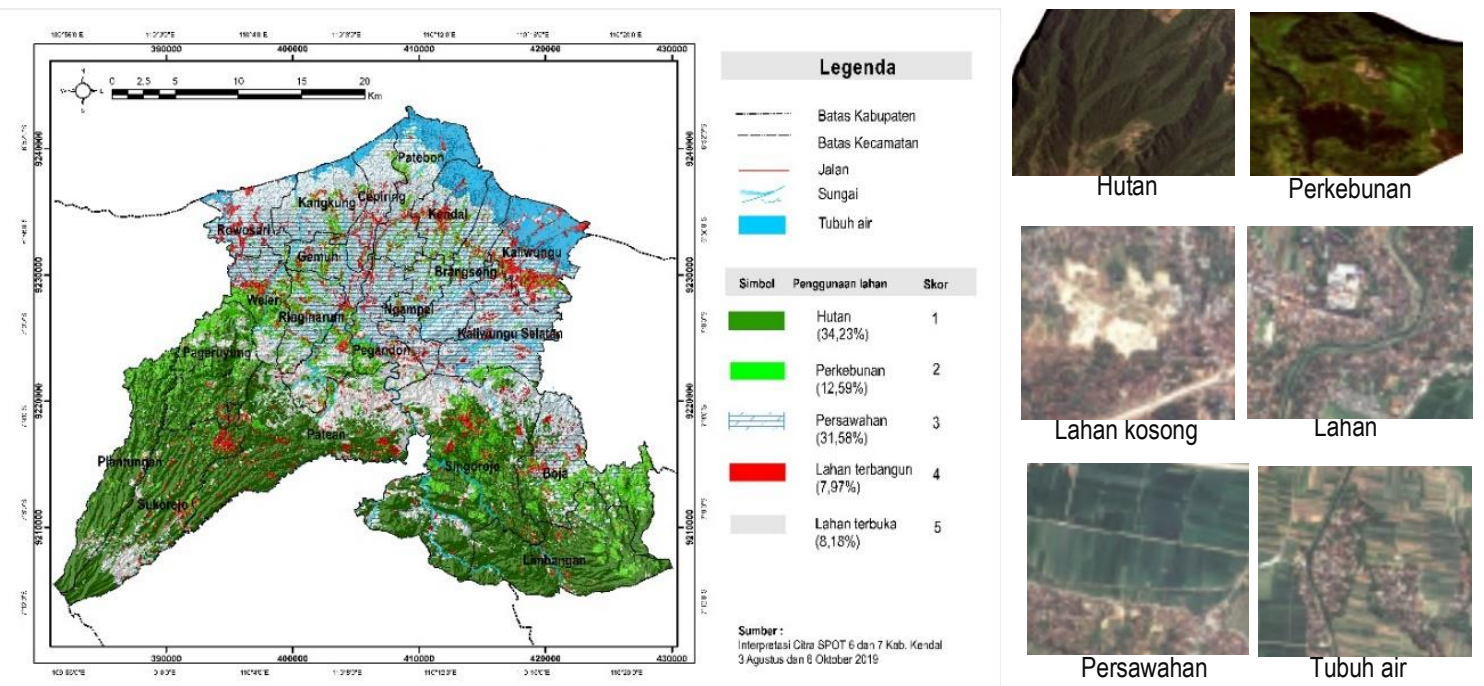

Gambar 5. Interpretasi penggunaan lahan Kabupaten Kendal.

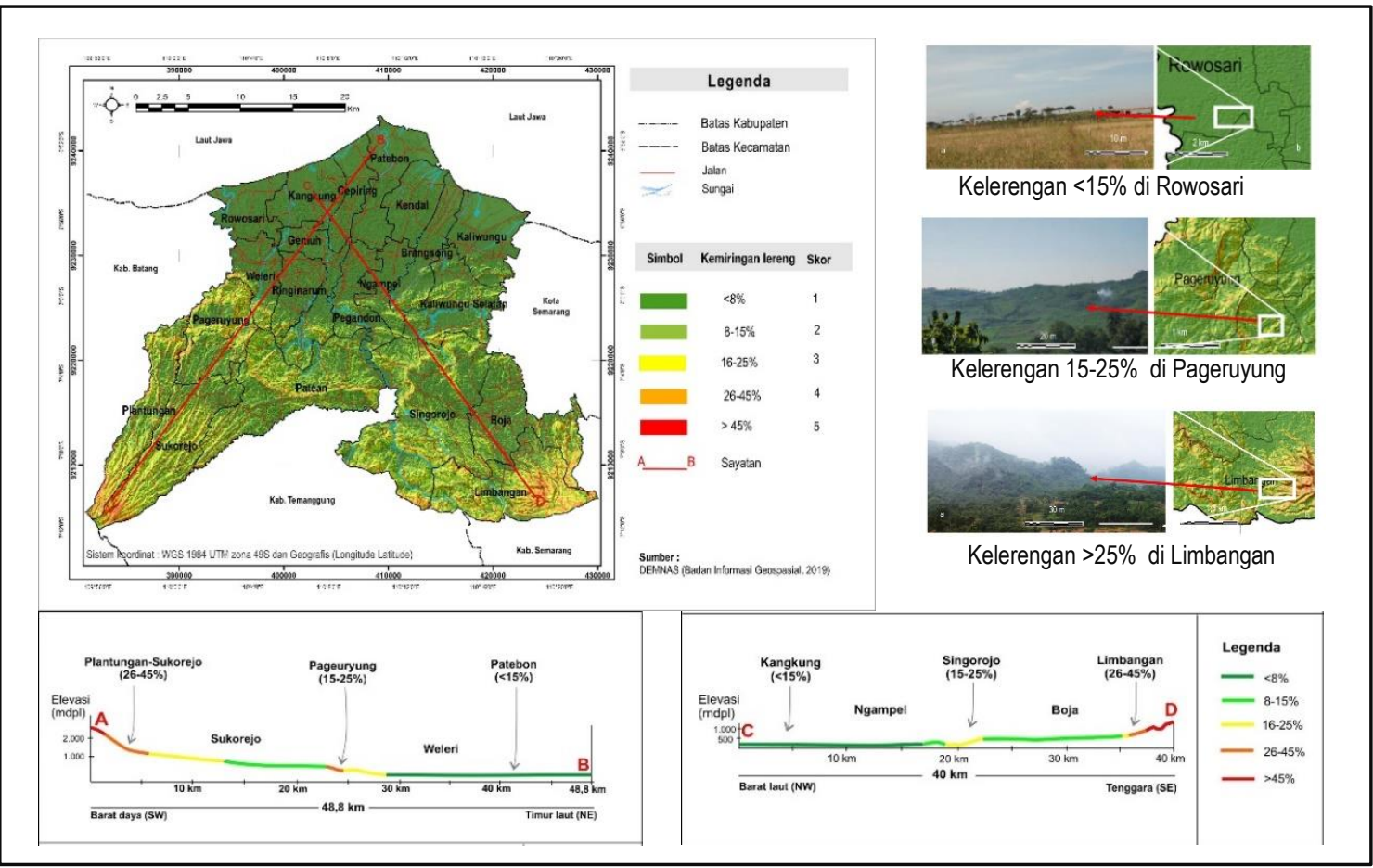

Gambar 6. Kemiringan lereng dan sayatan topografi Kabupaten Kendal. 
Tabel 3. Rincian pembobotan kemiringan lereng.

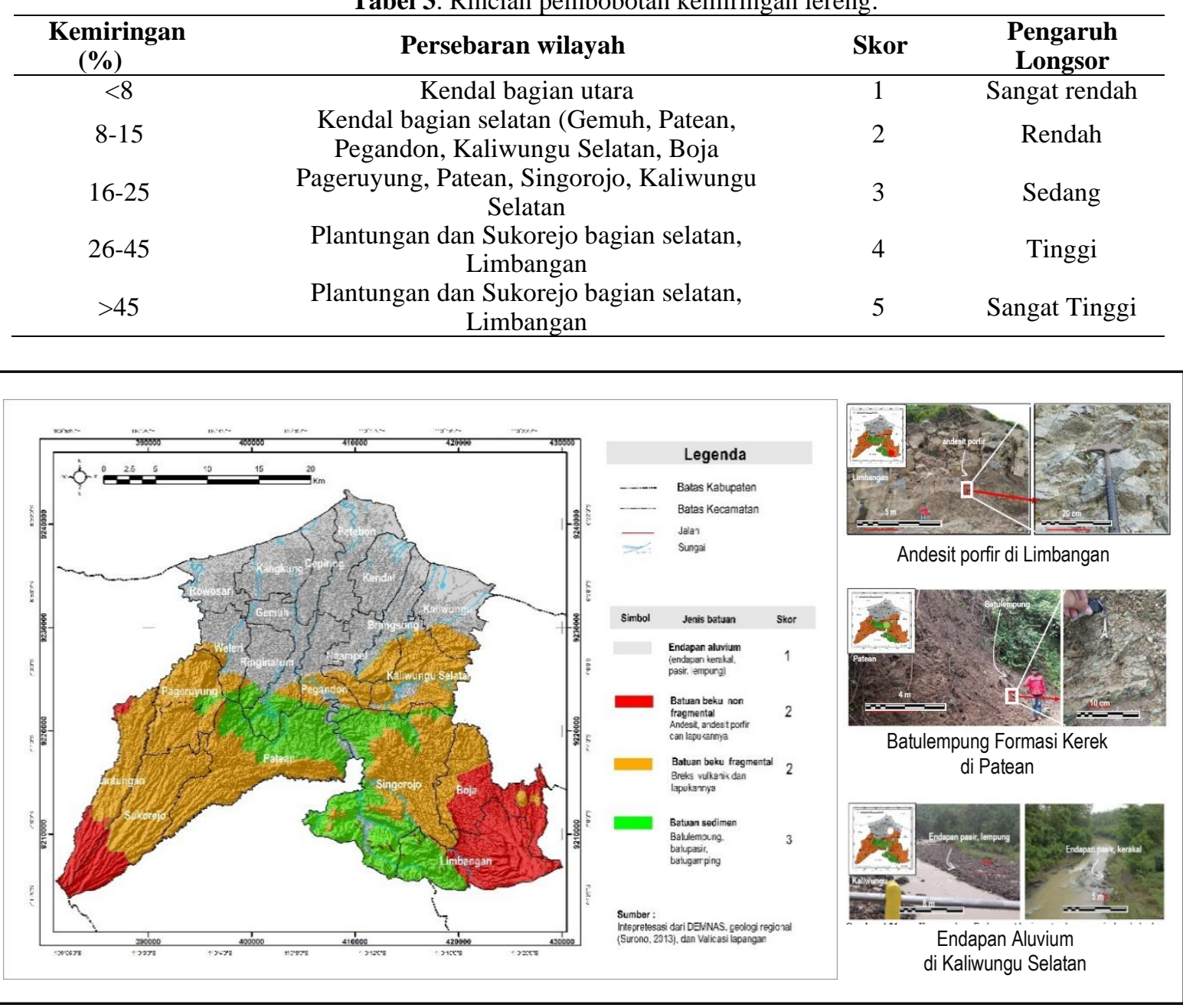

Gambar 6. Interpretasi jenis batuan Kabupaten Kendal dan kondisi lapangan.

Tabel 4. Rincian pembobotan jenis batuan.

\begin{tabular}{lllll}
\hline \multicolumn{1}{c}{ Jenis batuan } & \multicolumn{1}{c}{ Litologi } & \multicolumn{1}{c}{ Formasi } & Skor & \multicolumn{1}{c}{$\begin{array}{c}\text { Pengaruh } \\
\text { Longsor }\end{array}$} \\
\hline Endapan alluvium & $\begin{array}{l}\text { Endapan kerakal, pasir, } \\
\text { lempung }\end{array}$ & Aluvium & 1 & Sangat rendah \\
Batuan beku & $\begin{array}{l}\text { Andesit, andesit porfir, } \\
\text { breksi vulkanik }\end{array}$ & $\begin{array}{l}\text { Jongkong, Jembangan, } \\
\text { Kaligesik, Damar } \\
\text { Gajahmungkur, }\end{array}$ & 2 & Rendah \\
Batuan sedimen & Batulempung, batupasir & Kerek, Penyatan & 3 & Sedang \\
\hline
\end{tabular}

baratdaya dan tenggara merupakan daerah berbukit terjal (Gambar 6). Semakin besar presentase kemiringan lereng, maka semakin mudah terjadi longsor dikarenakan faktor kekuatan dan kemiringan lereng serta gravitasi akan memudahkan bergerak menuruni lereng. Kemiringan lereng mempengaruhi longsor sebanyak $35 \%$.

\section{Jenis Batuan}

Pada citra DEMNAS, batuan beku dicirikan morfologi lereng cukup terjal, terdapat pada lereng pegunungan yang dicirikan pola aliran radial, teksturnya cenderung kasar, mengikuti lereng. Batuan sedimen dicirikan tekstur cukup kasar, terdapat beberapa kenampakan indikasi lipatan, sesar yang diakibatkan aktivitas tektonik Plio-Pleistosen (Thanden, dkk, 1996) berada pada ketinggian lebih landai dari batuan beku. Aluvium umumnya bertekstur halus, berasosiasi dengan sungai-sungai yang memiliki indikasi 
stadia sungai dewasa , berada pada daerah datar.

Batuan yang ditemui di lapangan antara lain andesit porfir, andesit, breksi vulkanik, batulempung, batupasir, batugamping, serta endapan pasir-kerakal (aluvium). Endapan aluvium berupa material lepasan berukuran pasir, lempung, kerikil, dan kerakal memiliki tingkat potensi yang paling rendah dengan nilai 1 (sangat rendah), karena material yang belum terkompaksi dan keberadaannya berada pada daerah yang relatif landai sehingga sangat kecil kemungkinan untuk terjadi longsor (Sutanto, 2011). Batuan beku fragmental maupun nonfragmental memiliki tingkat potensi 2 (rendah) karena faktor kekuatan batuannya yang cenderung lebih kompak, sulit menyimpan air, dan lebih keras dari batuan sedimen maupun endapan aluvium. Batuan sedimen memilki nilai potensi 3 (sedang) karena sifatnya yang agak untuk mengalirkan air (batulempung) dan cenderung menyimpan air (Impermeable) pada batupasir dan batugamping. Selain mudah rapuh, air pada batuan juga dapat mempengaruhi daya ikat antar butirnya sehingga batuan menjadi lebih rentan. Hal ini sesuai dengan Sutanto (2011) yang menyatakan bahwa batuan sedimen memiliki tingkat potensi sedang untuk mempengaruhi longsor. Faktor jenis batuan mempengaruhi $25 \%$ dari keseluruhan faktor potensi longsor. Hal ini dijelaskan pada Gambar 7 dan Tabel 4.

\section{Jarak dari Kelurusan}

Interpretasi kelurusan untuk mengetahui potensi zona lemah yang dapat memicu longsor. Kelurusan banyak ditemukan pada daerah Limbangan, Singorojo, Kaliwungu Selatan, Patean, Sukorejo, Pageruyung, dan Boja. Bukti hancuran yang paling tampak adalah kekar-kekar di daerah Kedungboto, Limbangan pada Formasi Gajahmungkur (litologi andesit) yang berbatasan dengan litologi batulempung di bawahnya. Formasi Penyatan dan Gajahmungkur di geologi regional berbentuk cukup tegas sehingga memperkuat bukti kelurusan di daerah ini diindikasikan sebagai patahan. Adanya banyak mataair juga menjadi indikasi adanya zona lemah keluarnya air ke permukaan akibat patahan, dan terdapat 180 mata air di Kabupaten Kendal (PSDA Jawa Tengah, 2006). Makin dekat dengan kelurusan, makin besar potensi terjadi longsor, hal ini dijelaskan pada Tabel 5 dan Gambar 7. Jarak kelurusan mempengaruhi longsor $10 \%$.

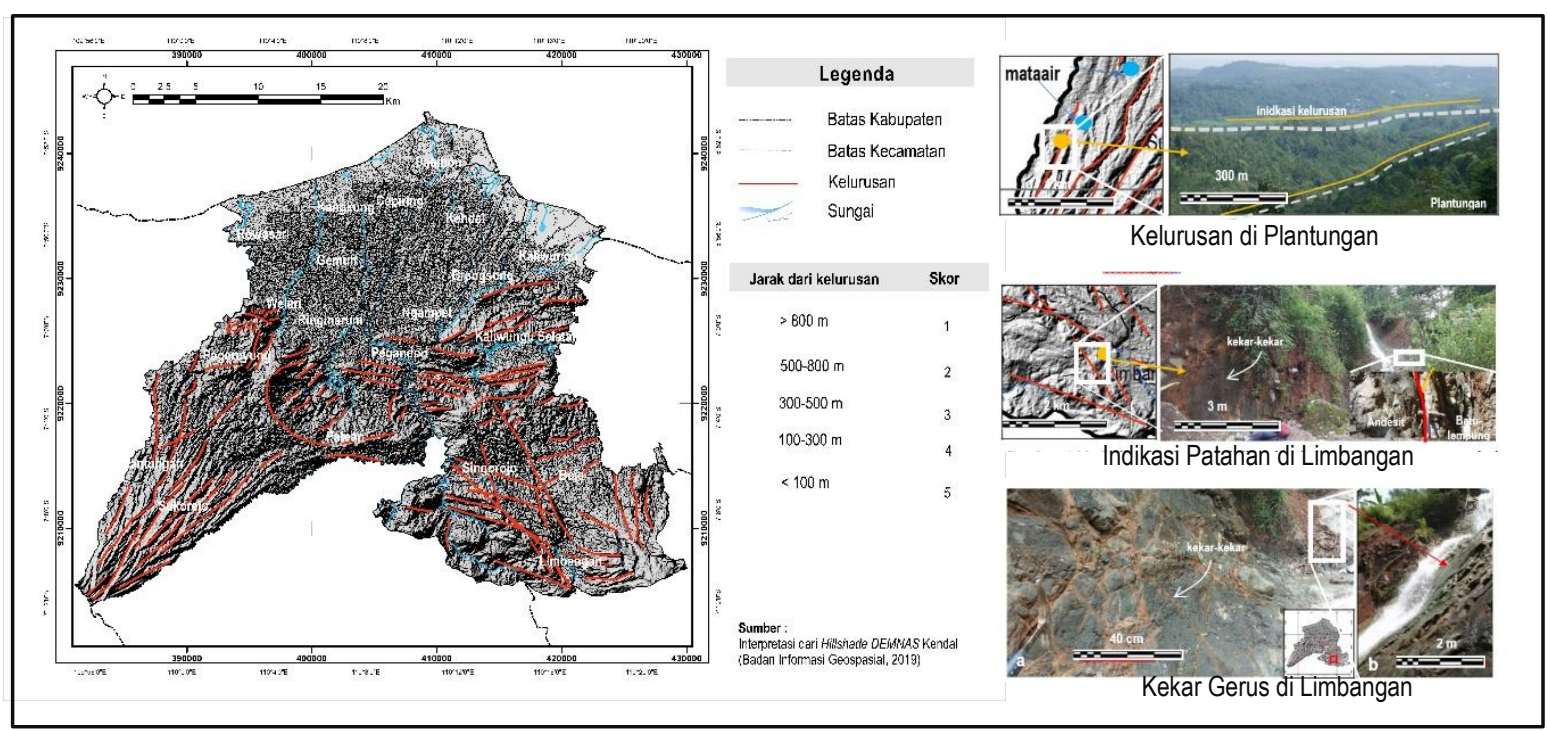

Gambar 7. Interpretasi Kelurusan Kabupaten Kendal dan kondisi lapangan.

Tabel 5. Rincian pembobotan jarak dari kelurusan.

\begin{tabular}{ccc}
\hline Jarak dari kelurusan & Skor & Pengaruh terhadap longsor \\
\hline$>800 \mathrm{~m}$ & 1 & Sangat rendah \\
$501-800 \mathrm{~m}$ & 2 & Rendah \\
$301-500 \mathrm{~m}$ & 3 & Sedang \\
$100-300 \mathrm{~m}$ & 4 & Tinggi \\
$<100 \mathrm{~m}$ & 5 & Sangat tinggi \\
\hline
\end{tabular}




\section{Curah Hujan}

Secara umum, curah hujan tertinggi berada pada bulan Januari dan Februari. Curah hujan tertinggi terdapat pada Januari (500-712 $\mathrm{mm} / \mathrm{bulan})$, terendah pada Juli (28-11 mm/bulan). Hasil rerata curah hujan tahun 2019 menunjukkan bahwa daerah Kendal bagian selatan memiliki curah hujan yang sangat tinggi (2.501-3.197 mm/tahun) di daerah Limbanganbagian selatan. Daerah Boja, Singorojo, Plantungan, Sukorejo, dan Patean memiliki rataan curah hujan antara 2.001$2.500 \mathrm{~mm} /$ tahun. Daerah lain (Kendal bagian utara) cenderung memiliki tingkat curah hujan yang lebih rendah yakni kurang dari 2.000 $\mathrm{mm} /$ tahun. Curah hujan paling rendah berada pada daerah Rowosari dan Kaliwungu Utara dengan nilai curah hujan $1.997 \mathrm{~mm} / \mathrm{tahun}$ (Gambar 8 dan Tabel 6).

Curah hujan faktor penting dalam potensi longsor, dikarenakan pada musim penghujan yang umumnya longsor terjadi pada bulan Desember sampai Maret intensitas longsor juga semakin tinggi. Curah hujan mempengaruhi longsor sebanyak $20 \%$.

\section{Potensi Longsor}

Potensi longsor dari hasil pembobotan kemiringan lereng (35\%), jenis batuan (25\%), curah hujan (20\%), jarak dari kelurusan (10\%), dan penggunaan lahan (10\%) menhasilkan nilai 1,1-4,1 yang terbagi beberapa zona (Gambar 9) meliputi :

\section{Potensi Longsor Rendah}

Potensi longsor rendah $(44,05 \%$ atau 44.220 $\mathrm{Ha}$ ) berada pada Kendal bagian utara meliputi Kota Kendal, Patebon, Kaliwungu Utara, Brangsong, Kangkung, Patebon, Cepiring, Rowosari, Weleri utara, Gemuh bagian utara, Pegandon bagian utara, dan Brangsong bagian utara. Pada wilayah ini penggunaan lahan banyak digunaan untuk persawahan, pemukiman, dan tambak pada bagian utara. Kemiringan lereng sangat landai cenderung datar, curah hujan rendah (kurang dari 2.000 $\mathrm{mm} /$ tahun), tersusun oleh endapan aluvium di permukaan, serta tak dijumpai kelurusan.

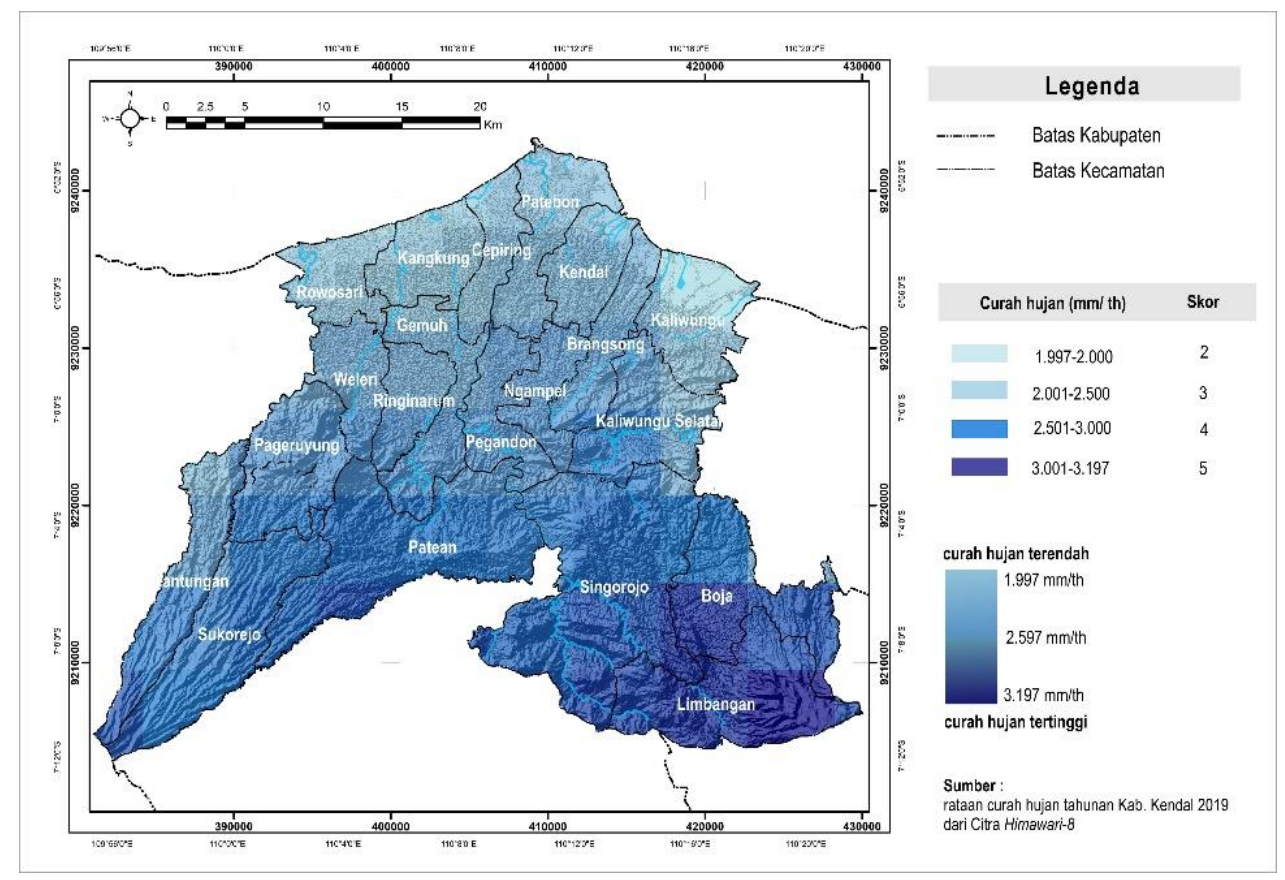

Gambar 8. Curah Hujan Kabupaten Kendal 2019 (Citra Himawari-8).

Tabel 6. Rincian pembobotan curah hujan.

\begin{tabular}{|c|c|c|c|}
\hline $\begin{array}{c}\text { Curah Hujan } \\
\text { (mm/ tahun) }\end{array}$ & Persebaran wilayah & Skor & $\begin{array}{l}\text { Pengaruh } \\
\text { Longsor }\end{array}$ \\
\hline $1.997-2.000$ & Kota Kendal, Rowosari, Kaliwungu & 2 & Rendah \\
\hline $2.001-2.500$ & $\begin{array}{l}\text { Boja, Singorojo, Plantungam Sukorejo, } \\
\text { dan Patean }\end{array}$ & 3 & Sedang \\
\hline $2.501-3.000$ & Limbangan & 4 & Tinggi \\
\hline 3.197 & Limbangan selatan & 5 & Sangat tinggi \\
\hline
\end{tabular}


Berdasarkan riwayat longsor dari BPBD Kabupaten Kendal, pada 2010-2020 terjadi 5 longsor pada tanggul sungai.

\section{Potensi Longsor Sedang}

Potensi longsor yang sedang $(50,47 \%$ atau $50.661 \mathrm{Ha})$ berada pada daerah Singorojo, Kaliwungu Selatan, Boja, Plantungan dan Sukorejo bagian utara, Pegandon bagian selatan serta Patean bagian selatan. Pada wilayah ini kemiringan lereng cukup landai, tetapi tidak datar. Curah hujan antara 1.000$2.000 \mathrm{~mm} / \mathrm{tahun}$, terindikasi beberapa kelurusan namun tidak banyak, jenis batuan terdiri atas batulempung, batugamping, batupasir dan batuan beku fragmental (breksi vulkanik), serta penggunaan lahan yang didominasi persawahan, pemukiman, perkebunan, dan hutan.

\section{Potensi Longsor Tinggi}

Potensi longsor tinggi $(5,48 \%$ atau $5.500 \mathrm{Ha})$ meliputi Singorojo bagian utara, Sukorejo dan Plantungan, Pageruyung bagian timur, Limbangan bagian barat, serta Patean bagian utara. Wilayah ini memiliki kemiringan lereng cenderung cukup terjal hingga terjal. Kemiringan lereng ini juga menjadi salah satu faktor paling besar potensi longsor.
Penggunaan lahan didominasi oleh perkebunan, lahan terbuka, pemukiman, serta hutan. Keberadaannya yang berada pada sepanjang lahan terbangun (jalan) terutama pada Pageruyung bagian timur dan Patean dianjurkan untuk melakukan langkah pencegahan. Batuan penyusun didominasi oleh batuan sedimen (batulempung) dan batuan beku fragmental (breksi vulkanik dan andesit), memiliki curah hujan 2.000-2.500 $\mathrm{mm} /$ tahun.

\section{Potensi Longsor Sangat Tinggi}

Daerah dengan potensi longsor sangat tinggi $(0,001 \%$ atau 1,3 Ha) meliputi daerah Sriwulan, Sumber Rahayu Limbangan. Pada daerah ini tersusun atas batuan batuan beku (breksi vulkanik). Curah hujan pada daerah ini tergolong tinggi sampai sangat tinggi (3.197 $\mathrm{mm} /$ tahun). Kemiringan lereng cenderung terjal hingga sangat terjal. Penggunaan lahan pada daerah ini diominasi hutan dan perkebunan.

Matriks konfusi digunakan untuk mengetahui, merangkum serta membandingkan range nilai pembobotan pada setiap faktor yang ditampilkan pada Gambar 10, sedangkan kondisi lapangan ditampilkan pada Gambar 11.

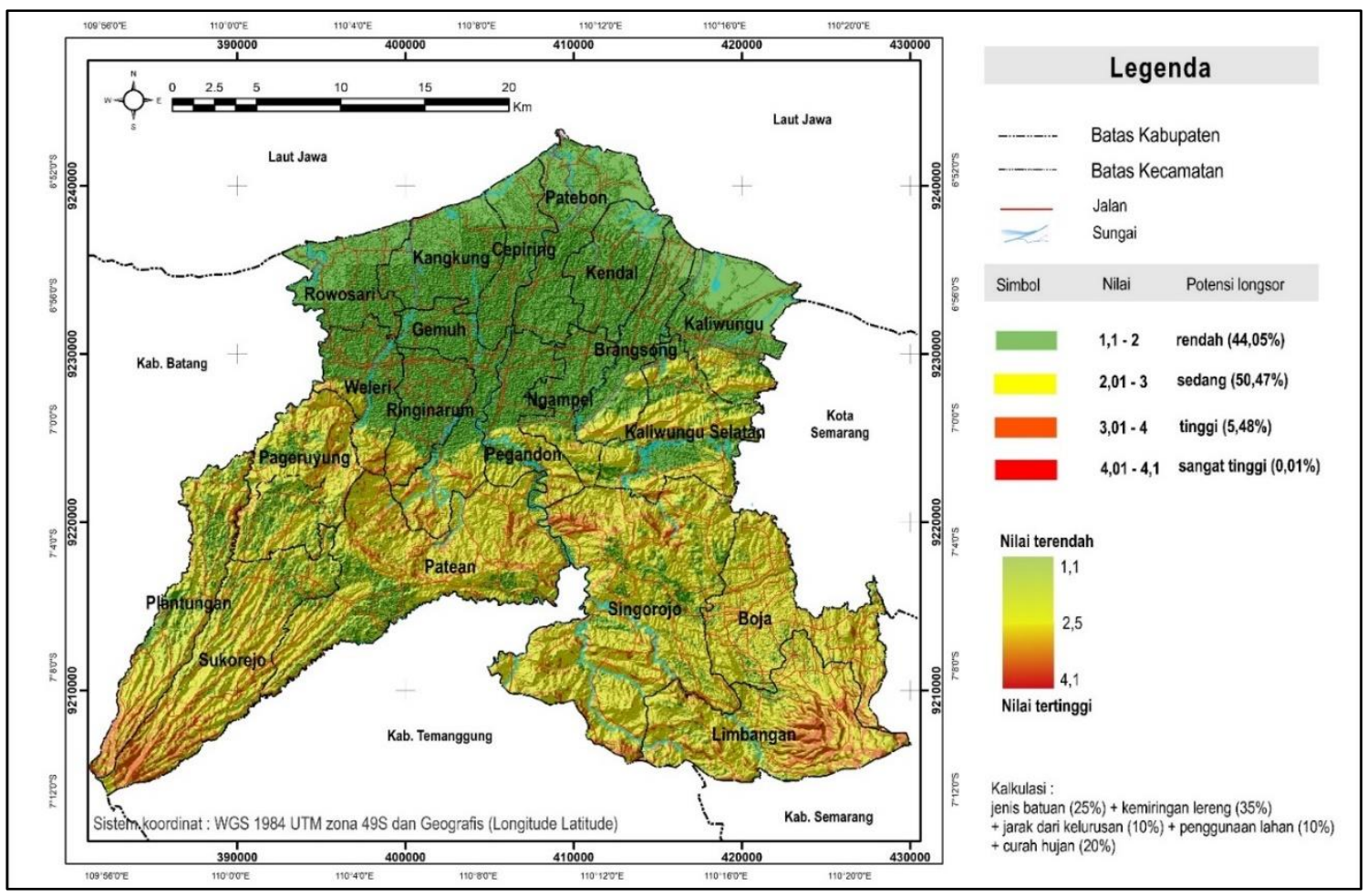

Gambar 9. Peta Potensi Longsor Kabupaten Kendal. 


\begin{tabular}{|c|c|c|c|}
\hline Potensi longsor & $\begin{array}{l}\text { Penggunaan Lahan } \\
\qquad(10 \%)\end{array}$ & $\begin{array}{l}\text { Jarak dari kelurusan } \\
\qquad(10 \%)\end{array}$ & $\begin{array}{l}\text { Curah Hujan } \\
\qquad(20 \%)\end{array}$ \\
\hline 1,1-2 rendah & $\begin{array}{l}\text { hutan, perkebunan, persawahan, } \\
\text { lahan terbangun } \\
\text { (nilai 1-4) }\end{array}$ & $\begin{array}{l}>800 \mathrm{~m} \\
\text { (nilai 1) }\end{array}$ & $\begin{array}{l}1.997-2.000 \mathrm{~mm} / \mathrm{th}, 2.001-2.500 \\
\mathrm{~mm} / \mathrm{th}, 2.501-3.000 \mathrm{~mm} / \mathrm{th} \\
\text { (nilai } 2-4 \text { ) }\end{array}$ \\
\hline $2,01-3$ sedang & $\begin{array}{l}\text { hutan, perkebunan, persawahan, } \\
\text { lahan terbangun, lahan terbuka } \\
\text { (nilai 1-5) }\end{array}$ & $\begin{array}{c}100-300 \mathrm{~m}, 301-500 \mathrm{~m} .501-800 \mathrm{~m}, \\
\text { (nilai } 1-4)\end{array}$ & $\begin{array}{l}2.001-2.500 \mathrm{~mm} / \mathrm{th} \\
2.501-3.000 \mathrm{~mm} / \mathrm{th} \\
\text { (nilai } 3-4 \text { ) }\end{array}$ \\
\hline $3,01-4$ tinggi & $\begin{array}{l}\text { hutan, perkebunan, persawahan, } \\
\text { lahan terbangun, lahan terbuka } \\
\text { (nilai } 1-5 \text { ) }\end{array}$ & $\begin{array}{c}<100 \mathrm{~m}, 301-500 \mathrm{~m} .501-800 \mathrm{~m}, \\
\text { (nilai 3-5) }\end{array}$ & $\begin{array}{l}2.001-2.500 \mathrm{~mm} / \mathrm{th}, 2.501-3.000 \\
\mathrm{~mm} / \mathrm{th}, 3.001-3.197 \mathrm{~mm} / \mathrm{th} \\
\text { (nilai } 3-5)\end{array}$ \\
\hline $4,01-4,1$ sangat tinggi & $\begin{array}{l}\text { perkebunan, persawahan, } \\
\text { lahan terbangun } \\
\text { (nilai 2-4) }\end{array}$ & $\begin{array}{l}<100 \mathrm{~m} \\
\text { (nilai 5) }\end{array}$ & $\begin{array}{l}3.197 \mathrm{~mm} / \mathrm{th} \\
\text { (nilai 5) }\end{array}$ \\
\hline $\begin{array}{l}\text { Jenis Batuan } \\
\qquad(25 \%)\end{array}$ & $\begin{array}{l}\text { Kemiringan Lereng } \\
(35 \%)\end{array}$ & \multicolumn{2}{|c|}{ Persebaran Daerah (luas) } \\
\hline $\begin{array}{l}\text { Endapan aluvium, batuan beku (andesit, } \\
\text { andesit porfir, breksi vulkanik) } \\
\text { (nilai } 1-2 \text { ) }\end{array}$ & $\begin{array}{l}<8 \% \\
\text { (nilai 1) }\end{array}$ & \multicolumn{2}{|c|}{$\begin{array}{l}\text { Kota Kendal, Patebon, Kaliwungu Utara, Brangsong, } \\
\text { Kangkung, Patebon, Cepiring, Rowosari, Weleri, Pegandon, } \\
\text { Ringinarum bagian utara, dan Gemuh bagian utara }(43.220,31 \mathrm{Ha})\end{array}$} \\
\hline $\begin{array}{l}\text { batuan beku (andesit,andesit porfir, } \\
\text { breksi vulkanik) batuan sedimenn } \\
\text { batulempung, batupasir, batugamping) } \\
\text { (nilai 2-3) }\end{array}$ & $\begin{array}{l}<8 \%, 8-15 \%, 16-25 \% \\
\quad \text { (nilai } 1-3 \text { ) }\end{array}$ & \multicolumn{2}{|c|}{$\begin{array}{c}\text { Kaliwungu Selatan, Boja, Plantungan bagian utara, Sukorejo bagian } \\
\text { utara, Pegandon bagian selatan, Patean bagian selatan, Gemuh bagian selatan, } \\
\text { Ngampel bagian utara, Ringinarum bagian selatan } \\
\text { bagian selatan }(50.661,12 \mathrm{Ha})\end{array}$} \\
\hline $\begin{array}{l}\text { batuan beku (andesit,andesit porfir, } \\
\text { breksi vulkanik) batuan sedimenn } \\
\text { batulempung, batupasir, batugamping) } \\
\text { (nilai 2-3) }\end{array}$ & $\begin{array}{l}16-25 \%, 26-45 \%,>45 \% \\
\text { (nilai 3-5) }\end{array}$ & \multicolumn{2}{|c|}{$\begin{array}{c}\text { Singorojo bagian utara, Sukorejo bagian selatan, Plantungan bagian selatan, } \\
\text { Singorojo bagian barat dan utara, Limbangan bagian selatan dan barat, serta Patean } \\
\text { bagian utara }(5.500,67 \mathrm{Ha})\end{array}$} \\
\hline $\begin{array}{l}\text { batuan beku (andesit ) } \\
\text { (nilai 2) }\end{array}$ & $\begin{array}{l}>45 \% \\
\text { (nilai 5) }\end{array}$ & \multicolumn{2}{|c|}{ Sumber Rahayu dan Sriwulan Kecamatan Limbangan (1,3 Ha) } \\
\hline
\end{tabular}

Gambar 10. Matriks konfusi pembobotan, parameter, hasil dan persebaran potensi longsor.

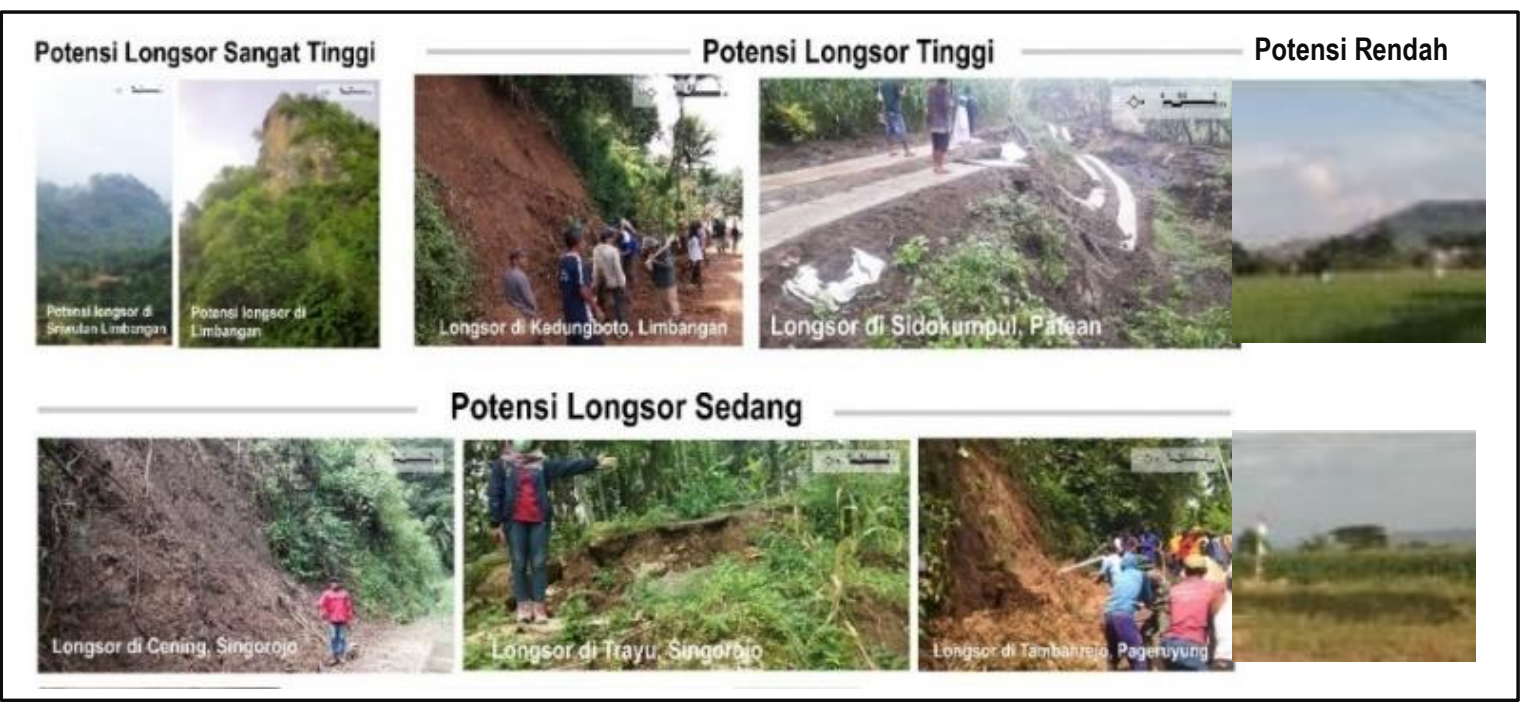

Gambar 11. Matriks konfusi pembobotan, parameter, hasil dan persebaran potensi longsor. 


\section{Validasi Longsor dan Jenis Batuan}

Tercatat tidak kurang dari 200 titik longsor telah terjadi pada antara tahun 2010 sampai 2020, berdasarkan pengamatan langsung di lapangan dan data riwayat kejadian longsor pada BPBD Kabupaten Kendal. Titik terbanyak tersebar di sekitar Patean. Titik longsor yang berada pada zona potensi rendah berada pada tanggul sungai karena banjir sungai.
Umumnya, jenis longsor yang ditemui adalah rockfall yang terjadi pada batuan beku serta slide dan debris flow pada batuan sedimen. Beberapa juga ditemukan indikasi jenis longsoran tipe nendatan. Kenampakan validasi titik longsor di lapangan dapat dilihat pada Gambar 12 dan Gambar 13. Validasi jenis batuan ditampilkan pada Gambar 14

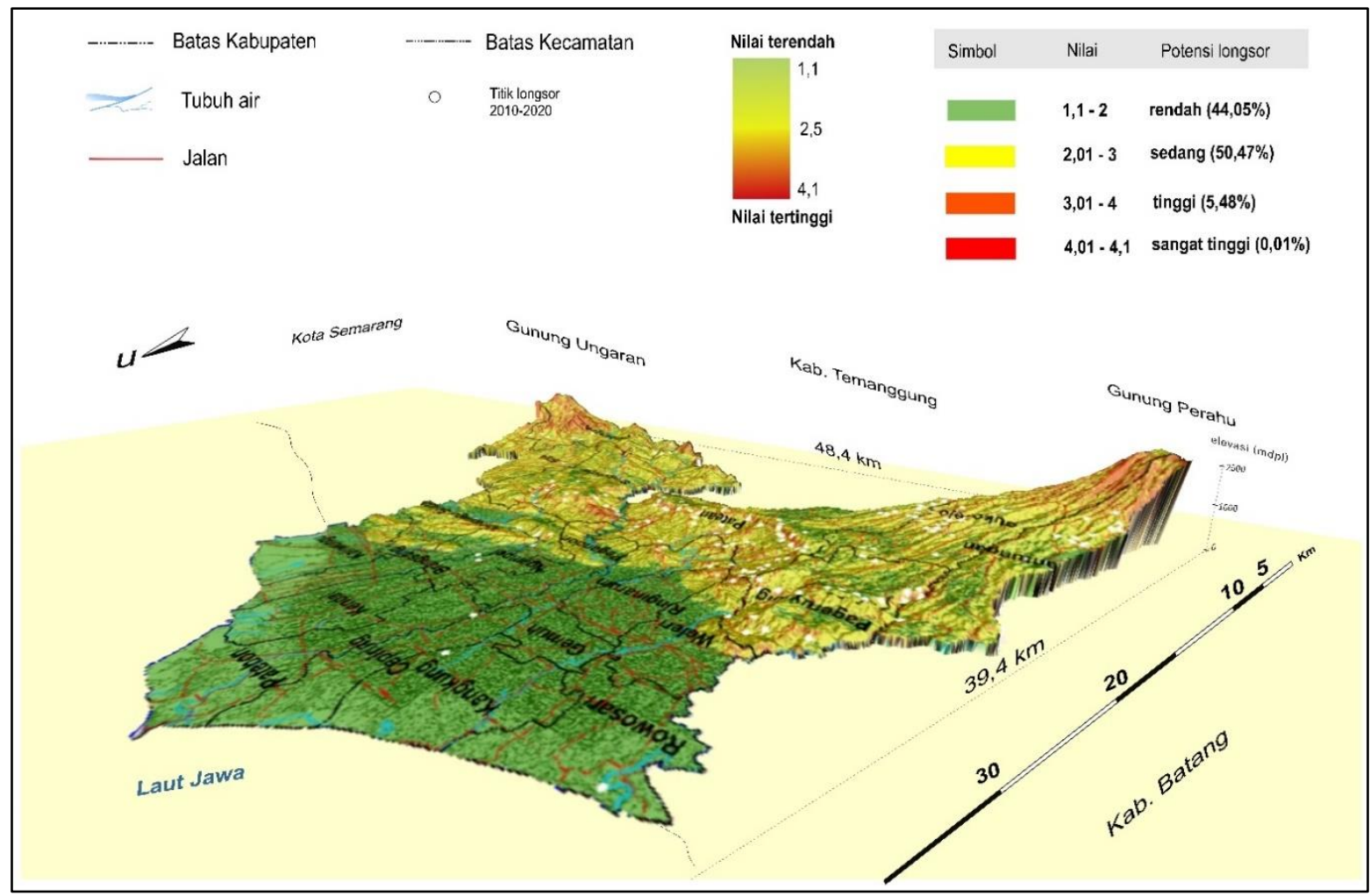

Gambar 12. Validasi Titik Longsor dari BPBD Kendal dan pengamatan lapangan.

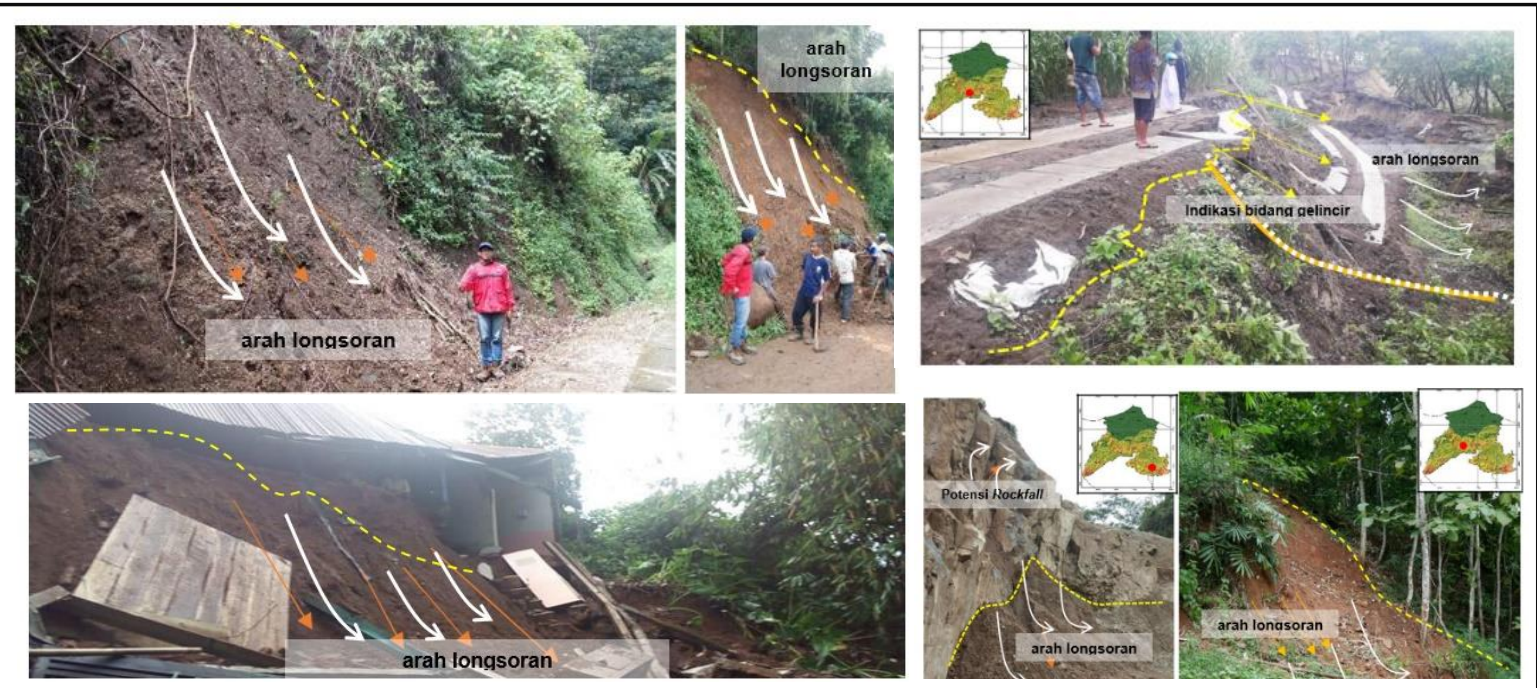

Gambar 13. Validasi Titik Longsor dari BPBD Kendal dan pengamatan lapangan. 


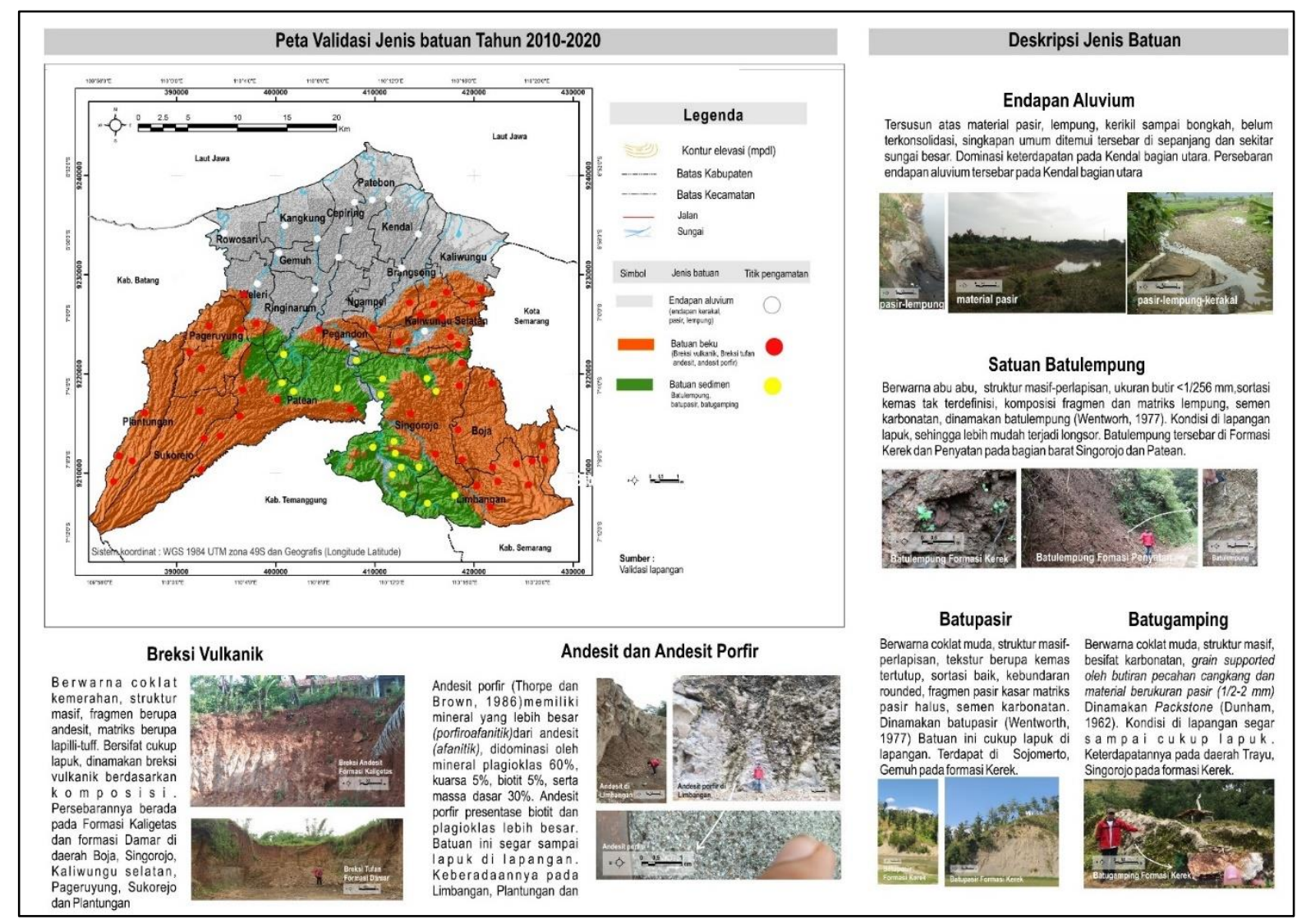

Gambar 14. Validasi jenis batuan.

\section{KESIMPULAN}

Potensi longsor rendah $(44,05 \%$ atau $44.220 \mathrm{Ha})$ meliputi Kendal bagian utara Potensi longsor sedang $(50,47 \%$ atau $50.661 \quad \mathrm{Ha})$ meliputi Kaliwungu Selatan, Boja, Plantungan utara ,Sukorejo utara, Pegandon selatan, Gemuh selatan dan sekitarnya. Potensi longsor tinggi $(5,48 \%$ atau $5.501 \mathrm{Ha})$ meliputi Singorojo utara dan barat, Sukorejo selatan, Plantungan selatan, Pageruyung timur, Limbangan barat dan selatan, serta Patean utara. Potensi longsor sangat tinggi $(0,001 \%$ atau 1,3 Ha) meliputi daerah Sumber Rahayu dan Sriwulan Kecamatan Limbangan.

\section{UCAPAN TERIMA KASIH}

Terima kasih kepada PUSFATJA LAPAN, BPBD Kabupaten Kendal yang menyediakan keperluan data terkait penelitian ini.

\section{DAFTAR PUSTAKA}

BBPPSDLP (Balai Besar Litbang Sumberdaya Lahan Pertanian), 2009. Identifikasi dan Karakterisasi Lahan Rawan longsor dan Rawan Erosi di Dataran Tinggi untuk Mendukung Keberlanjutan Pengelolaan
Sumberdaya Lahan Pertanian. Laporan Tengah Tahun, DIPA Bogor: Balai Besar Litbang Sumberdaya Lahan Pertanian

BPBD (Badan Penanggulangan Bencana Daerah) Kendal, 2020. Rowayat longsor Kendal 20102020. Kendal : Badan Penanggulangan Bencana Daerah Kabupaten Kendal

CCRS (Canada Centre for Remote Sensing ) 2018. Fundamental of Remote Sensing. Kanada: Canada Center for Remote Sensing.

Dewi, T.S., Kusumayudha S.B., Purwanto, H.S., 2017. Zonasi Rawan Bencana Tanah Longsor Dengan Metode Analisis Gis: Studi Kasus Daerah Semono Dan Sekitarnya, Kecamatan Bagelen, Kabupaten Purworejo, Jawa Tengah. Jurnal Mineral, Energi dan Lingkungan 1.

DVMBG (Direktorat Vulkanologi dan Mitigasi Bencana Geologi), 2004. Penyusunan dan Penentuan Zona Kerentanan Gerakan Tanah. Direktorat Vulkanologi dan Mitigasi Bencana Geologi.

Emiyati, 2012. Hydrologic Response Unit (HRU) Dan Debit Aliran Daerah Aliran Ci Rasea. Depok : Fakultas Matematika Dan Ilmu Pengetahuan Alam Program Pascasarjana 
Magister Ilmu Geografi Departemen Geografi Universitas Indonesia.

Highland, L.M., dan Bobrowsky, P. 2008. United States Geological Survey. Virginia : United States Geological Society. Hal. 96-99.

Kushardono, D., 2012. Kajian Satelit Penginderaan Jauh Cuaca Generasi Baru Himawari 8 dan 9. Jurnal Inderaja 3(5).

LAPAN (Lembaga Penerbangan dan Antariksa Nasional), 2019. Citra SPOT 6/7 Panchromatic daerah Kendal, Semarang dan Sekitarnya

Lillesand. T. dan Kiefer, R.W., 1979. Remote Sensing and Image Interpretation. New York: John Willey and Sons.

Liu, J. G. dan Mason, P.J., 2016. Image Processing and GIS For Remote Sensing. John Wiley \& Sons, Ltd.

Nichol, J. dan Wong, M.S., 2005a. Detection and Interpretation of Landslide using Sateliite Images. Land Degradation \& Development 16(3). DOI: https://doi.org/10.1002/ldr.648.

Nichol, J. dan Wong, M.S., 2005b. Satellite Remote Sensing for Detailed Landslide Inventories using Change Detection and Image Fusion. International Journal of Remote Sensing 26(9). DOI: https://doi.org/10.1080/014311605123313140 47.

PSDA (Pusat Sumber Daya Air Jawa Tengah), 2006. Inventarisasi Mata Air Jawa Tengah 2006. Semarang : Pusat Sumber Daya Air Jawa Tengah Jawa Tengah.

PVMBG (Pusat Vulkanologi dan Mitigasi Bencana Geologi), 2015. RSNI Penyusunan dan Penentuan Zona Kerentanan Gerakan Tanah. Yogyakarta: Pusat Vulkanologi dan Mitigasi Bencana Geologi.

PVMBG (Pusat Vulkanologi dan Mitigasi Bencana Geologi), 2019. Data dan Informasi Kebencanaan Indonesia (DIBI). Yogyakarta: Pusat Vulkanologi dan Mitigasi Bencana Geologi.

PVMBG (Pusat Vulkanologi dan Mitigasi Bencana Geologi), 2020. Peta Prakiraan
Kerentanan Longsor Kabupaten Kendal bulan Januari. Yogyakarta: Pusat Vulkanologi dan Mitigasi Bencana Geologi.

Sukojo, B.M. dan Prastika, C., 2018. Landslie Hazard Analysis in Tuban Regency Using Multilevel Satelllite Imagery Processing for Landslide Potential Mapping. IOP Conference Series : Earth and Environmental Science (186).

Surono, 2013. Geologi Regional Hasil Penginderaan Jauh. Bandung : Pusat Survey Geologi.

Thanden, R.E., Richards, P.W., dan Sumadirdja, H., 1996. Peta Geologi Lembar Magelang dan Semarang, Jawa. Bandung: Direktorat Geologi.

Thannoun, R.G., 2003. Automatic Extraction and Geospatial Analysis of Lineaments and their Tectonic Significance in some areas of Northern Iraq using Remote Sensing Techniques and GIS. International Journal of Enhanced Research in Science Technology \& Engineering 2(2).

van Zuidam, R.A., 1985. Geomorphology. diakses dari

https://www.academia.edu/10099249/buku_va n_zuidam pada 15 Agustus 2020.

Varnes, D.J., 1978. Slope movement types and process, Special Report 176; Landslides; Analysis and Control, Eds: R.L. Schuster dan R.J. Krizek, Transport Research Board, National Research Council, Washigton, DC.

Yu, B., dan Chen, F, 2017. A new Technique for Landslide Mapping from a Large-Scale Remote Sensed Image : A Case Study of Central Nepal. Beijng : Chinese Academy of Science. hal.115-124.

Zhong, C., Liu, Y., Gao, P., Chen, W., Li, H., Hou, Y., Nuremanguli, T., dan Ma, H., 2019. Landslide Mapping with Remote Sensing : Challenges and Opportunities. International Journal of Remote Sensing 41(4). DOI: https://doi.org/10.1080/01431161.2019.16729 04. 